\title{
Analisis Faktor-Faktor Penyebab Ketidaklengkapan Pengisian Lembar Resume Medis Pasien Rawat Inap
}

\author{
Desy Riyantika ${ }^{1}$ \\ ${ }^{1}$ STIKes Surya Mitra Husada Kediri \\ Email : desyriyantika28@gmail.com
}

Received 21 April 2018; Accepted 8 May 2018; Published 15 May 2018

\begin{abstract}
ABSTRAK
Jurnal ini bertujuan untuk menganalisis faktor-faktor penyebab ketidaklengkapan pengisian lembar resume medis pasien rawat inap. Jenis penelitian ini menggunakan penelitian deskriptif dengan pendekatan kualitatif. Subyek pada penelitian ini terdiri dari dokter,perawat dan petugas rekam medis. Dari hasil kelima jurnal menyatakan bahwa kesibukan dokter dan kurangnya sarana prasarana pendukung di rumah sakit yang menyebabkan ketidaklengkapan pengisian resume medis.
\end{abstract}

Kata Kunci : Faktor ketidaklengkapan, resume medis.

Copyright $\odot 2018$ STIKes Surya Mitra Husada

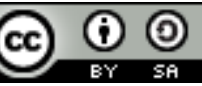

This is an open-acces article distributed under the terms of the Creative Commons Attribution-ShareAlike 4.0 International License. 


\section{PENDAHULUAN}

Rumah Sakit adalah salah satu pemberi layanan kesehatan yang mempunyai tanggung jawab untuk meningkatkan mutu pelayanan kesehatan yang diberikan kepada masyarakat. Rumah sakit memiliki fungsi utama untuk memberikan perawatan dan pengobatan yang sempurna kepada pasien baik pasien rawat inap, rawat jalan maupun gawat darurat. (Azwar, 1996).

Salah satu parameter untuk menentukan mutu pelayanan medis di rumah sakit adalah data/informasi dari rekam medis. Sehingga untuk memenuhi pelayanan mutu tersebut maka banyak upaya yang dapat dilakukan, maka jika tujuan utamanya untuk memenuhi mutu pelayanan yang diselenggarakan oleh suatu pelayanan, objek kajian yang dipandang paling sesuai adalah rekam medis (Azwar,1996).

Rekam medis berfungsi untuk memelihara dan menyediakan informasi bagi semua pihak yang terlibat dalam memberikan pelayanan kesehatan kepada pasien. Rekam medis harus berisi informasi yang memadai mengenai pasien, menurut data penegakan diagnosis dan pengobatan cedera atau luka. Rekam medis adalah berkas yang berisikan catatan dan dokumen tentang identitas pasien, pemeriksaan, pengobatan, tindakan dan pelayanan yang telah diberikan kepada pasien (Peraturan Menteri Kesehatan Republik Indonesia Nomor 269/Menkes/III/2008).

Kualitas rekam medis dapat dilihat pada kelengkapan, kesesuaian, serta kevalidan isinya, dapat juga dilihat dengan terlindungi atau tidaknya kerahasiaan informasi yang terkandung di dalamnya. Rekam medis disebut lengkap apabila catatan medis tersebut telah berisi seluruh informasi tentang pasien, sesuai dengan formulir yang disediakan, isi harus lengkap dan benar, khususnya resume medis dan resume keperawatan termasuk seluru hasil pemeriksaan penunjang (Depkes RI. 1997).

Rumah sakit mempunyai kewajiban dalam penyelenggaraan rekam medis. Hal ini tertuang dalam Undang-Undang RI No. 29 Tahun 2004 tentang Praktik Kedokteran paragraf 3 rekam medis Pasal 46 menyatakan : 1) Setiap dokter atau dokter gigi dalam menjalankan praktik kedokteran, wajib membuat rekam medis; 2) rekam medis sebagaimana dimaksud pada ayat (1) harus segera dilengkapi setelah pasien menerima pelayanan kesehatan. Bila yang bersangkutan dengan sengaja tidak membuat rekam medis sebagaimana yang dimaksud dalam pasal 79, maka dokter/dokter gigi dapat dipidana kurungan 1 tahun atau denda Rp 50.000.000,

Salah satu bagian dari berkas rekam medis yang sering tidak terisi lengkap adalah lembar resume medis. Menurut Depkes RI. (2006), resume medis adalah berisi ringkasan tentang penemuan-penemuan, dan kejadian penting selama pasien dirawat, keadaan waktu pulang, dan rencana pengobatan selanjutnya. Kelengkapan resume medis pasien sangat penting karena berkaitan dengan pengobatan pasien dan pengklaiman BPJS.

\section{METODE}

Jenis penelitian yang dilakukan menurut keempat jurnal menggunakan penelitian deskriptif dengan pendekatan kualitatif. Sedangkan menurut Indar (2013 ) penelitian yang dilakukan merupakan penelitian kuantitatif dengan pendekatan survey analitik. Pengambilan sample pada penelitian ini menggunakan purpossive sample dan accidental sampling. Subyek pada penelitian ini terdiri dari seorang dokter, perawat dan petugas rekam medis.

Variabel dalam penelitian ini adalah faktor-faktor penyebab ketidaklengkapan lembar resume medis pasien rawat inap. 


\section{HASIL DAN PEMBAHASAN PENELITIAN}

\section{Faktor Predisposisi (Sumber Daya Manusia)}

Dokter mengetahui bahwa resume medis merupakan catatan medis yang penting dan harus diisi lengkap karena berkaitan dengan riwayat penyakit pasien selama dirawat di rumah sakit. Namun pengetahuan mengenai resume medis tidak cukup menjamin individu untuk berperilaku patuh dalam melengkapi lembar resume medis tepat waktu. Petugas Rekam medis dan perawat menyatakan beban kerja terlalu banyak. Sedangkan adanya petugas rekam medis, perawat dan dokter yang merangkap pekerjaan.

Kendala yang mempengaruhi dokter dalam pengisian lembar resume medisbahwa menurut dokter kendala yang menyebabkan ketidaklengkapan resume medis adalah kesibukan, sudah ditunggu pasien di poli atau sudah ditunggu di rumah sakit lain. Alasan lain penyebab ketidaklengkapan berkas rekam medis menurut wawancara dengan dokter didapat hasil bahwa ketidaklengkapan pengisian

berkas rekam medis disebabkan oleh kurangnya kesadaran dari dokter akan pentingnya kelengkapan pengisian berkas rekam medis dan ketidakdisiplinan dari dokter yang bertanggung jawab merawat pasien. Namun hal ini seharusnya tidak dijadikan alasan oleh dokter untuk tidak melengkapi rekam medis, khususnya resume medis karena merupakan kewajiban dokter. Kelengkapan data rekam medis pasien merupakan tanggung jawab setiap dokter.

\section{Faktor Pendukung (Sarana)}

Sarana yang disediakan disesuaikan menurut kemampuan dari rumah sakit yang bersangkutan. Menurut kepala rekam medis, rumah sakit menyediakan lembar check list dan ruang komite medis untuk menunjang kelengkapan pengisian resume medis.

Kendala yang dialami dokter dengan ada atau tidaknya sarana yang menunjang pengisian resume medisdiketahui bahwa sarana yang disediakan oleh pihak rumah sakit sudah cukup baik sehingga sarana tidak menjadi penyebab ketidaklengkapan pengisian resume medis. Rumah sakit telah menyediakan lembar check list dan ruangan komite medis. Akan tetapi menurut 2 jurnal yang lainnya, kurang tersedianya sarana ruang kerja dokter, ruang assembling menjadi penyebab untuk belum melengkapi pengisian resume medis.

\section{Faktor Pendorong (Prosedur dan Kebijakan)}

Terkait faktor pendorong yaitu prosedur dan kebijakan, menurut dokter, perawat, dan kepala rekam medis tidak ada kendala terkait Standar Operasional Prosedur (SOP) mengenai resume medis. Standar Operasional Prosedur (SOP) sudah sesuai yang berisi mengenai kewenangan, kebijakan dan prosedur tentang rekam medis dan resume medis yang harus dipatuhi oleh dokter.

Dari ketiga faktor yang diteliti yaitu faktor predisposisi (sumber daya manusia), faktor pendukung (sarana), dan faktor pendorong (kebijakan dan prosedur) yang menjadi penyebab utama dari ketidaklengkapan pengisian resume medis adalah faktor sumber daya manusia. Kesibukan dijadikan alasan utama oleh dokter tidak melengkapi resume medis, namun seharusnya kesibukan itu tidak dijadikan alasan. Karena membuat resume medis, melengkapi resume medis adalah kewajiban seorang dokter. Seperti yang dijelaskan di UU praktik kedokteran No.29 pasal 46 ayat (1) menyatakan bahwa setiap dokter atau dokter gigi dalam menjalankan praktik kedokteran wajib membuat rekam medis.

Perawat berhak untuk menulis identitas pasien pada setiap formulir rekam medis dengan melihat pada Form Ringkasan Masuk Keluar, yaitu No. RM, nama, umur, kelas, sedangkan riwayat penyakit pasien tetap menjadi kewenangan dokter. Walaupun dengan adanya kebijakan tersebut, tanggung jawab kelengkapan resume medis tetap berada di tangan dokter dan walaupun perawat hanya menulis identitas pasien, namun perawat juga harus mengisi identitas dengan lengkap. 


\section{KESIMPULAN DAN SARAN}

\section{Kesimpulan} berikut :

Berdasarkan hasil penelitian dan pembahasan diatas, dapat disimpulkan sebagai

1. Faktor presdiposisi (sumber daya manusia) yang menjadi penyebab utama ketidaklengkapan pengisian resume medis yaitu karena kesibukan dokter sehingga menyebabkan keterlambatan dalam kelengkapan resume medis.

2. Faktor pendukung (sarana) tidak menjadi penyebab ketidaklengkapan resume medis di Rumah Sakit 'Aisyiyah Ponorogo. Karena pihak rumah sakit sudah menyediakan sarana untuk menunjang kelengkapan resume medis.

3. Faktor pendorong (kebijakan dan prosedur) disimpulkan bahwa faktor prosedur tidak menyebabkan ketidaklengkapan resume medis. Karena sebenarnya sudah ada peraturan dan kebijakan yang dikeluarkan oleh pihak rumah sakit untuk menunjang kelengkapan resume medis, yaitu dengan teguran lisan maupun teguran tertulis.

\section{SARAN}

1. Diperlukan kerjasama yang lebih intensif dari pihak-pihak yang terkait khususnya antara perawat, petugas rekam medis dengan dokter yang menangani pasien sehingga berkas rekam medis pasien rawat inap terutama resume medis dapat terisi dengan lengkap dan lebih baik lagi.

2. Diperlukan sosialisasi yang optimal tentang kebijakan pengisian rekam medis sehingga dokter, perawat dan petugas rekam medis maupun pihak lain yang terkait mengetahui dan memahami akan pentingnya kelengkapan berkas rekam medis khususnya resume medis.

3. Disarankan diadakan pembinaan kepadadokter dalam hal pengisian dokumen rekam medis dan memberikan pelatihaninteren mengenai penentuan diagnosis utama sesuai dengan ketentuan ICD-10,agar para dokter dapat meningkatkan pengetahuan mereka tentang kelengkapan pengisian rekam medis.

4. Meningkatkan motivasi dokter dalam pengisian rekammedis melalui pengembangan karier, promosi dan pemberian umpan balik denganmemberikan reward dan punishment.

\section{DAFTAR PUSTAKA}

Anggraeni, \& ayu. (2017). Faktor-Faktor Penyebab Ketidaklengkapan Resume Medis Pasien Rawat Inap di RS Griya Waluya Ponorogo. STIKES Buana Husada Ponorogo.

Azwar, \& Azrul. (1996). Prosedur Administrasi Kesehatan. Jakarta : Bina Aksara Rupa.

Depkes. (2006). Pedoman Penyelenggaraan Dan Prosedur Rekam Medis Rumah Sakit Di Indonesia. Jakarta : Depkes RI.

Irmawati, \& Indar. (2013). Faktor Yang Berhubungan Dengan Kelengkapan Rekam Medis Di Rsud H. Padjonga Dg. NgalleTakalar 2013. Fakultas Kesehatan Masyarakat. Universitas Hassanuddin.

Lihawa, \& Cicilia. (2015). Faktor-faktor Penyebab Ketidaklengkapan Pengisian Rekam Medis Dokter di Ruang Rawat Inap RSI Unisma Malang. Fakultas Kedokteran Universitas Brawijaya Malang.

Maharani, \& Wahyatunnisa. (2005). Tinjauan Faktor Penyebab Ketidaklengkapan Dokumen Rekam MedisRawat Jalan Di Balai Kesehatan Paru Masyarakat (Bkpm) Semarang Tahun 2015.Fakultas Kesehatan Universitas Dian Nuswantoro Semarang. 
Pamungkas, \& Wahyu, T. (2010). Analisis Ketidaklengkapan Pengisian Berkas Rekam Medis Di Rumah Sakit Pku Muhammadiyah Yogyakarta. Fakultas Kesehatan Masyarakat. Universitas Ahmad Dahlan. Yogyakarta.

Peraturan Menteri Kesehatan Republik Indonesia Nomor 269/Menkes/Per/III/ 2008 Tentang Rekam Medis. Jakarta : Departemen Kesehatan Republik Indonesia.

Peraturan Pemerintah Republik Indonesia nomor 32 tahun 1996 tentang Tenaga Kesehatan. Undang-Undang Nomor 29 Tahun 2004 Tentang Praktik Kedokteran. 